\title{
Viajando pela história através de artefatos humanos
}

\section{Visiting history through human artifacts}

https://doi.org/10.34112/2317-0972a2016v34n66p155-158

\section{Ezequiel Theodoro da Silva ${ }^{1}$}

MacGregor, Neil. A história do mundo em 100 objetos. Trad. Ana Beatriz

Rodrigues, Berilo Vargas e Cláudio Figueiredo. Rio de Janeiro: Intrínseca, 2013. 784 p.

ESSE LIVRO CHEGOU-ME ÀS MÃOS COMO UM PRESENTE de aniversário em fevereiro de 2014. O amigo que me presentou me informou que a obra trazia, colada na contracapa, uma etiqueta de troca da livraria caso eu viesse a não gostar do conteúdo. Confesso que me assustei com a grossura e com as 784 páginas impressas em letras meio miúdas - dois fatores que, numa primeira aproximação e no contexto da pressa dos dias de hoje, assustam qualquer freguês. Mas, como livro é um presente amigo vindo de outro amigo, resolvi verificar se eu me encantaria com o texto. Como tinha outras coisas mais urgentes para ler à época, resolvi deixar os "10o objetos" um pouco de molho, para voltar a eles num momento mais espaçoso em termos de ocupação e tarefas por fazer, o que veio a ocorrer três meses depois, bem contados.

O livro me seduziu logo na leitura do primeiro capítulo. Deixei-o na cabeceira da minha cama para ir entendendo e curtindo os objetos lentamente, aos poucos, antes do sono chegar. Por vezes eu vibrava tanto com aquilo que se passava nas

1. Universidade Alto Rio do Peixe, Caçador, SC, Brasil. 
narrativas do livro, que tive de ler vários trechos ou capítulos inteiros para a minha esposa, curiosa que ficava com as minhas vibrações na hora de dormir. E isso aconteceu várias vezes no transcorrer dessa fruição alongada, que me ocupou por quase um ano. E confesso que foi um daqueles textos que a gente deseja que nunca termine porque prazeroso de ler, porque bem articulado e extremamente revelador.

Os 100 objetos foram selecionados a partir de uma criteriosa análise do acervo do Museu Britânico (British Museum), fundado em 1753 e situado em Londres, Inglaterra. Pode-se imaginar o rigor dessa seleção tomando como base acervo atual do museu: mais de 8 milhões de peças. Vale lembrar que os 100 artefatos tratados neste livro procuram cobrir nada menos do que dois milhões de anos de história. A contracapa informa que "O relato é conduzido pelos mais variados artefatos que o homem produziu, concebidos cuidadosamente para serem admirados e preservados ou para serem usados, danificados e descartados.” Assim, o leitor tem a oportunidade de fazer uma viagem de leitura desde os primórdios da história (2.000.000-900 a.C.) começando pela Múmia de Hornedjitef, até chegar à primeira década do Século 21 através da análise da significação, dentre outros, do cartão de crédito e da lâmpada fotovoltaica.

Importante sublinhar que o livro foi editado a partir de um programa da rádio $\mathrm{BBC}$, transmitido em 2010, tendo por coordenador Mark Damazer, que também estabeleceu os parâmetros e as regras para a escolha dos objetos:

[...] colegas do Museu e da BBC escolheriam do acervo do British Museum cem objetos de um período que começasse nos primórdios da história da humanidade, há aproximadamente dois milhões de anos, e chegasse até os dias atuais. As peças tinham que abranger o mundo inteiro, da forma mais igualitária possível. Tentariam tratar de tantos aspectos da experiência humana quanto fosse viável e nos falariam de sociedades inteiras, não apenas dos ricos e poderosos. Precisavam incluir, portanto, artigos humildes da vida cotidiana e grandes obras de arte. (p. 13).

Comentaristas qualificados foram chamados para contextualizar os artefatos de modo a produzir compreensão pelos ouvintes da rádio; posteriormente, as suas falas foram gravadas e inseridas no livro, mantendo o tom descontraído, coloquial. Resultou desse processo uma obra impecável em termos editoriais, fartamente ilustrada por fotos (também impecáveis) e, ao final, um mapa apontando os locais onde as peças foram encontradas, antes de seguirem para o British Museum em Londres. 
O movimento de construção dos capítulos, cada qual representando um objeto específico, segue uma lógica mais ou menos comum, que vai da narração-descrição à contextualização. Mais especificamente, o autor apresenta o artefato na linha da história, destaca a sua importância para o desenvolvimento humano, descreve os seus pormenores e o contextualiza, ampliando a sua significação para os leitores. Dentro desse movimento, surge a voz de analistas ou comentaristas altamente gabaritados, iluminando aqueles aspectos tematizados. Ainda em termos de estrutura, ao final da obra são arrolados todos os objetos, as suas dimensões, os números no inventário do British Museum e as páginas em que são tratados no presente livro. Some-se a esses elementos uma bibliografia relacionada a cada um dos 100 objetos, as referências contidas nos capítulos e um índice remissivo mais do que completo, com um alto poder de orientação didática.

No prefácio, intitulado "Missão impossível”, o autor afirma que "a função dos museus é contar histórias utilizando objetos” (p. 13). Mais especificamente, aos museus incumbe a tarefa de "reunir a memória de nossos antepassados e desvendar como era a vida das pessoas em outras épocas. Cada relíquia recuperada é uma possibilidade de enxergar um mundo antigo com novos olhos e compreender melhor o passado" ( $1^{a}$ orelha). Sendo assim, a substância deste livro, extraída a partir de diferentes objetos criados pelo homem, conduz o olhar do leitor para uma compreensão profunda das fases históricas desde o momento em que os nossos ancestrais deixaram a África Oriental para povoar o mundo e, nos diferentes trajetos percorridos, geraram experiência e produziram ferramentas para sobreviver, conviver e enriquecer-se culturalmente. Dessa forma, para além de conhecer - e muito - as dimensões do trabalho museológico propriamente dito, assentadas aqui e ali nos cem capítulos, tornamo-nos testemunhas do alto poder criador dos homens ao longo da sua existência em sociedade.

Não cabe aqui recuperar e explicitar aquilo que é falado a respeito de cada objeto - isto deixamos para os leitores o fazerem, caso se sintam atraídos pelo desenho geral contido nesta resenha. Quer dizer, o detalhamento de 100 objetos tratados em sua profundidade seria praticamente impossível de produzir e muito possivelmente resultaria numa reprodução indigesta e/ou estafante. Muito mais do que isso, coube-nos enaltecer a qualidade gráfica, pedagógica e conteudística do livro, recomendando a sua leitura por todos aqueles que quiserem compreender melhor o mundo e compreender-se melhor dentro dele. Ou seja: realizar mais uma viagem 
maravilhosa de leitura, através daquilo que essa viagem geralmente possibilita, complexificar a nossa subjetividade e refinar os nossos conhecimentos.

SOBRE O AUTOR

Ezequiel Theodoro da Silva é graduado em Língua e Literatura Inglesa pela Pontifícia Universidade Católica de São Paulo (PUC-SP), Mestre em Educação - Leitura - pela University of Miami (UM) e Doutor em Educação também pela PUC-SP. Possui Livre Docência em Metodologia de Ensino pela Faculdade de Educação da Universidade Estadual de Campinas (UNICAMP). Atua como professor visitante junto ao Grupo de Pesquisa ALLE (Alfabetização, Leitura e Escrita), dessa mesma universidade e, em abril de 2015, passou a compor a equipe de professores pesquisadores do programa de Mestrado Interdisciplinar stricto sensu em Desenvolvimento e Sociedade da Universidade Alto Vale do Rio do Peixe (UNIARP). Em janeiro de 2016 assumiu a coordenação do Mestrado Profissional em Educação Básica da UNIARP. Comanda os trabalhos da Editora Leitura Crítica e o Portal Leitura Crítica, onde inseriu boa parte da sua obra e promove a formação continuada e a atualização dos professores brasileiros para o ensino da leitura.

E-mail: emarthi@outlook.com.br

Recebido em 13 de julho de 2015 e aprovado em o8 de novembro de 2015. 